\title{
LITERATURE FOR LIFE ${ }^{1}$
}

\author{
Ruenruthai Sujjapun ${ }^{2}$
}

\begin{abstract}
"Literature for life" is a unique type of Thai contemporary literature. It has risen to prominence in the history of Thai contemporary literature in at least two periods. The first period was between A.D.1947 and 1957 and the second was the October 14, 1973-October 6, 1976 era. Literature for life was influenced by the concept of "art for life's sake," which was much discussed in literary magazines between 1947 and 1957, particularly by Asni Phonlachan, who criticized traditional Thai literature from the point of view of "art for life's sake" and Udom Sisuwan, who saw Sri Burapha's novels as "literature for life". The concept of "art for art's sake" influenced not only critics but also writers during that decade. Literature for life returned to popularity in the period between October 14, 1973 (2516) and October 6, 1976 (2519) because of political conflict. Young activist writers expressing their beliefs in the need for social change made literature for life the mainstream of Thai literature during that time. Nowadays, political ideology being no longer so prominent an issue, literature for life is less powerful but still exits.
\end{abstract}

1 This paper was presented at the $7^{\text {th }}$ International Conference on Thai Studies, 4-8 July 1999, Amsterdam, The Netherlands.

${ }^{2}$ Department of Thai and Oriental Languages, Faculty of Humanities, Ramkhamhaeng University.

\section{Literature for Life in the initial period: $1947-1957$}

The term 'literature for life' might have been influenced by the concept of 'art for life's sake' publicized in many articles in various magazines during the 1947-1957 period.

In his articles under the pen-name 'Indrayuth', published in Aksonsan, monthly magazine, Asni Phonlachan used the idea of 'art for life's sake' in criticizing traditional literary works such as Sepha Khun Chang Khun Phaen, and Lilit Phra Lò. He believed in the theory that the place of the poet was side by side with the people and that literature must present the reality of life and society. 'Indrayuth' pointed out that these traditional Thai literary works were written in order to please the royal court and also to support feudalism, and that in some works, such as Lilit Phra Lò, even though the language was very poetic, the content was erotic. The aggressive tone of those critical articles was attacked by conservative readers, and many articles on the topic 'art or obscenity' were published in various newspapers and magazines of that time.

At the same time, Udom Sisuwan, in articles in Pituphoom and Mahachon under the pseudonym 'Pho. Muangchomphoo,' emphasized the idea that: 
'There is no 'art for art's sake' and there cannot be. There is only 'art for life's sake' because art is born from life and related to life ${ }^{3}$

In his article entitled 'Study the Literature from the Society, Study the Society from the Literature' published in Mahachon in 1950 , he also declared that;

'The art created by one devoted to the concept of 'art for art's sake,' whether he be conscious of it or not, whether he accept it or not, must partly concern itself in one way or another with existence in society. It must be a reflection of the economy and the politics surrounding him. ${ }^{4}$

In this same article, Udom criticized Sri Burapha's novel Khang Lang Phap [Behind the Picture] and said that this sad love-story was 'a product of the society which developed in the passing of time and the surroundings of that time. ${ }^{, 5}$ The tragic love of the heroine, who was distantly related to the royal line, was the tragedy of the aristocracy. In criticizing Chon Kwa Rao Cha Phop Kan Ik [Till We Meet Again], another of Sri Burapha's novels, he presented the idea that this novel 'demands the readers to acknowledge or try to acknowledge the reality of our society., ${ }^{, 6}$ At the conclusion of his article, he states:

${ }^{3}$ Banchong Banchoedsilp. 1981. Sinlapa Wannakhadi Kap Chiwit [Literary Art and Life]. (n.p.: Saithip, 1981), pp. 3, 56, 67.

${ }_{5}^{4}$ Ibid., p. 67.

${ }^{5}$ Ibid., p. 69.

${ }^{6}$ Ibid., p. 92. 'study the literature from the society and study the society from the literature--this is the right principle for judging the value of art. We must believe that art is for life and that life is the source of art. The word 'life' means the life of human society, which is composed of economy, politics, and culture."7

Banchong also stated that it was writers' perception of their literary mission in fighting for the rights of the poor that caused the concept of 'art for art's sake to develop into 'art for the people's sake.,

In 1955 Jit Phoumisak under the pen-name 'Tipakon' propagated a theory of literature based on socialist and Marxist thought and presented the idea of 'art for life's sake' through four long articles published in various magazines. These four articles are 'What is Art ?', 'Is there any pure art?", 'What is 'Art for Art's Sake'?' and 'What is the Exact Meaning of 'Art for Art's sake'?'. His writings were influenced by Tolstoy's 'What is Art?' and 'An Essay on Art' and by the work of various Western art critics. Jit gave this definition of 'art for life's sake:'

By 'art for life' is meant art whose successful results benefit the social life of the people; it is art that opens the people's eyes to see the origin of the wickedness in their lives; it is art that suggests that the people find their own right

\footnotetext{
${ }^{7}$ Ibid., p. 95.

${ }^{8}$ Ibid., p. 62.
} 
way out and arouses the people to fight and move towards the goal of better lives. 'Art for life' is art that is created to benefit the lives of the people as a whole.?

Jit also pointed out the four significant principles of literature for life, which were to:
1) reveal the ugliness of real life
2) reveal the origin of that ugliness
3) reveal ways to turn that
ugliness into the beauty
4) reveal examples of the beauty of the coming life.

Jit emphasized that the content of art should be significant to mankind and that forms must 'serve' and 'be acceptable' with their beauty, simplicity and clarity. ${ }^{10}$ $\mathrm{He}$ also stated that the function of art was to wake the people to face the objective reality of life and push them to change the ugliness of life into something better. ${ }^{11}$

These four articles were printed in 1957 under the title Art for Life. In the same year, Jit wrote an article entitled 'Art for the People' in order to point out that literature not only revealed the wickedness of life but also led the way to a better one. Moreover, literature should awaken people so that they become more conscious of their roles in changing their lives and their world. ${ }^{12}$ The two series of

9 Tipakon [Jit Phoumisak]. Sinlapa Pheua Chiwit, Sinlapa Phuea Prachachon [Art for Life, Art for the People]. (n.p.: Nangsu, 1972), pp. 121-122.

${ }_{10}$ Ibid., pp. 24-38.

${ }^{11}$ Ibid., p. 88.

${ }^{12}$ Ibid., p. 220. articles were printed in the book entitled Art for Life, Art for People in 1972.

Along with articles presenting the idea of 'art for life' widespread among activist writers, the 1947-1957 period of saw the birth of the 'literature for social justice' movement. This new trend in literary creation placed novels, short stories, poems and songs alongside the romantic 'best-seller' novels which dominated the reading market in the post-war period. ${ }^{13}$ The works were called "progressive" and the writers, mostly newspapermen, wrote about social problems, especially social injustice, violations of human rights, the gap between the rich and the poor, and the inequality between city and country. Notable early examples of this movement were Sri Burapha 's Nak Bun Chak Chanton [The Prophet from Chanton], Khon Phuak Nan [Those People], Khò Raeng Noi Thoe [Please Give Me a Hand], Kham Khan Rap [The Reply], U. Udakon 's Bon Phuen Phaen Din Thai [On The Land Of Thailand'], Indrayuth's Tò Trakun Mò [Continuing a Doctor's Family], Isra Amantakul's Chon Kwa Cha Thueng Satawat Haeng Pharadòraphap [Till the Century of Fraternity] and Khao Takon $\mathrm{Ha}$ Nayok Ratmontri [He Hollers for the Prime Minister], Sri Burapha's Chon Kwa Rao Cha Phop Kan Ik [Till We Meet Again], Seni Saowaphong's Khwam Rak Khòng Wanlaya [Wanlaya's Love] and Pisat [The Ghost], Srirat Sathapanawat's Phaen Din Ni Khong Khrai [Whose Land is This?] and Sokkanatakam Khòng Sat Mueang [Tragedy of the Citizen], and poems by Ujjeni, Thawipwon, Nai Phi, Plueang Wannasi etc. Nai Phi, or Asni

13 Trisilp Bunkajorn. The Novel and Thai Society (1932-1957). (n.p.: Sangsan, 1980), p. 277. 
Phonlachan, created his noted poem 'Isan,' which reflects the desolate and deserted country of the northeast of Thailand, to arouse the people to fight fate with their hearts and hands. He also wrote a long poem in chan entitiled 'Rao Chana Laeo Mae Cha' [Mother, We Have Won At Last!], which tells of the conflict between laborers and a factory owner. The female leader succeeds in negotiations but loses her mother and brother, who took ill during the rally.

Sri Burapha was the leader of the new generation thinkers. After his novel 'Khang Lang Phap' [Behind the Picture], written in 1937, the concepts of rights, liberty, and fraternity in society are increasing found in his writings. Sri Burapha believed that the mission of writers was to be responsible to their society. Speaking before a meeting of the Writers'Club, he said:

'the writer has a more distinctive responsibility than any other producers. While a chair or a shirt cannot change the user into a good or a bad guy, a book can do so. This is the reason why the writer must have a distinctive responsibility to the society ${ }^{, 14}$

Thus, Sri Burapha's prose fiction created the 'rebellious spirit,' a legacy for his contemporary writers and the 'avantguarde' university students of later times, in the period of 'searching for the truth' or the period of 'searching for the meaning of

14 Sathian Chanthimathon. Sai Than Wannakam Phuea Chiwit Khong Thai [The Stream of Thai Literature for Life]. (n.p.: Chao Phraya, 1982), p. 279. life' and especially in the October 14, 1973 , period. Sri Burapha's 'Kham Khan Rap' [The Reply], a short story, presents the idea of the aims and advantages education. He points out that education should not give only personal and individual advantages but must benefit the those who are not educated, who are the mass of the population of the country. This concept also is found in works by Seni Saowaphong. In Wanlaya's Love, Wanlaya decides to go back to her hometown upcountry to teach music to the children there, and in Pisat, Sai Sima decides to be a lawyer for the farmers in his home in order to fight against the selfish landlords.

Between 1947 and 1957, progressive literary works could not be published regularly because they were suppressed by the government. In 1952, under Phibun's military government, many newspapers were ordered closed, and many writers, newspapermen, publishers, and literary scholars were accused of being 'communists' or 'leftists.' Some were jailed because of their 'peace movement' and not freed until 1957. Under Sarit's military regime (1957-1963), many 'leftist' writers and journalists and thousands of common people were also arrested and jailed without trial. Sri Burapha, once a political prisoner, made a visit to China, took refuge there, and remained there until his death.

\section{Literature for Life in the pre- October 14 period}

The years of Sarit's dictatorial regime were said by the progressive writers to be the darkest time in their literary lives. The press was censored, political writings were banned, 'leftist' literary works were destroyed and those who opposed the government were suppressed. Many 
newspapers were ordered closed. A list of forbidden books was proclaimed, such as Mae [Mother], a novel translated by Sri Burapha, and Nitisat 2500, in which was published 'Chom Na Sakdina Thai' [The Face of Thai Feudalism], an article written by Jit Phoumisak. Many progressive writers were imprisoned, and those who remained free were threatened so much that some of them stopped writing and took up different work; for instance, Khamsing Srinok, or Lao Khamhom, who had written an outstanding collection of short stories $F a$ Bò Kan, turned to farming, while Seni Saowaphong, whose two famous novels Wanlaya's Love and Pisat are mentioned above, gave himself to his career at the Ministry of Foreign Affairs. Some progressive writers went to join the Communist Party of Thailand in the forest. Some, for example, Srirat Sathapanawat, Isra Amantakul, Rom Ratiwan, Chen Chetanatham, changed their style when released from jail, writing books catering to the reading market and no longer declaring their idealogy. Ujjeni, the only female poet, stopped writing poetry completely.

In this atmosphere of dictatorial repression and prison cells, Jit Phoumisak seems to have been the only activist writer who was unyielding in creating literature for life. During his imprisonment, he wrote many scholarly works such as $A$ Thai-Muser (Lahu) Dictionary and The Origin of Siam, Thai, Lao and Khom and the Social Characteristics of Those Nations. In addition, he wrote eleven songs, including The Lat Yao March, The Thai Farmer's March, Saeng Dao Haeng Sattha [Starlight of Faith], Ram Wong on May Day, and Saksri Khòng Raeng Ngan [The Dignity of the Labor]. Jit also wrote many poems, under his pennames 'Kawi
Kan Mueang' and 'Kawi Sri Siam'. He used the traditional versification and folk songs such as lam tat and phleng choi. The contents of his poems reflected mostly the sufferings of common people and laborers, the oppression of the ruler caste, the corruption of the tyrants and embezzling bureaucrats, and the crisis in rotten rural society, etc. A noted poem of Jit's was 'Winyan Nangsuephim, Kham Tuean Chak Phuean Kao Ik Khrang Nueng [Soul of the Newspaper, Another Warning From an Old Friend]. This poem warns newspapermen not to serve the dictator so much that they forgot the poor and suffering people. A part of this poem was often recited in rallies in later times and is one of the very favourite songs of life nowadays. This song is named 'Poep Khao' [Eating Rice].

Therefore, during Sarit's regime from 1958-1963, while censorship and political suppression were obstacles to the creation of progressive literature, fiction intended to rouse the readers' emotions more than thought practically dominated the literary scene. Ten years later such emotional fiction came to be called nam nao [stagnant water] because the plot, characterization, theme, and technique were cliché without any of the writers' individuality or creativity.

The 'literature for life' movement was revived after Sarit's death. After 6 years of the repressive atmosphere of dictator-ship, activist university students, young graduates, and scholars awakened and became involved in literary activities.

The launching of Sangkhomsat Parithat [Social Science Review] in 1963 by Sulak Sivarak, who was the publisher and the first editor, made a great contribution to the Thai literary scene. This magazine 
provided a stage for writers, scholars, and activist university students to freely express their views. Articles critical of the bureaucacy and dictatorship were published as well as social and political analyses. In the inaugural issue of Social Science Review, Sulak published a poem by Angkhan Kalayanaphong. Unlike popular love-poems, Angkhan's poem presented his profound concept of man, nature, and the universe with his unconventional use of poetic diction. His poems caused controversy among the reading public as well as literary scholars. The conventional poets condemned him as an 'aggressive' poet and criticized his versifications as wrong. But these two qualities influenced some young poets and scholars at that time. Besides publishing Angkhan's poetry, Sulak also printed Lao Khamhom's collection of short stories $\mathrm{Fa} B \dot{\mathrm{o}}$ $K a n$. These works awakened social consciousness in the minds and thought of the young readers. In 1965, Sulak published Social Science Review Student Edition, and this journal became a stage for the university students. In 1969, Suchat Sawatsri became the new editor of the Social Science Review monthly magazine. Various interesting academic articles were written by a new generation of intellectual elite. Short stories, poems and literary criticism were published regularly, including Nikhom Rayawa's short story 'Khon Dam Nam' [The Diver], Sujit Wongthes's short story 'Mao Nak Rian Nòk' [Drunk on Imported Students] and Chaisiri Samutwanit's critical article on Mueang Nimit [City in the Imagination], a political novel written by Nimitmongkhon Nawarat, an activist and writer of the 1932 revolution era.

Inside every university, there were many groups or clubs of university students who were interested in the political situation and the future of the country. These groups also carried on literary activities which were outlets allowing students to express their dissatisfaction with the social and political problems at that time. Cooperation of colleagues in seven universities led to the founding of Chet Sathaban [Seven Institutions], a pioneer student journal. This printed the short stories of famous progressive writers of the post-World War II era as well as various articles criticizing different social problems and political issues such as the Vietnam War. After Seven Institutions had been published for a short period of time, the editor and staff were interrogated by the police, and then, the journal had to close itself. However, after 1967, student groups carried on more political and social activities, both inside and outside the university, as well as literary activities. Later on, all these groups joined in establishing the Thailand Student Center, which took a very important part in the uprising of October 14, 1973. In order to express their thinking, they published 'Phai Khiao' [The Green Peril] on the danger of the military and 'Phai Khao' [The White Peril] on the danger of the western world, especially the United States of America, and 'Phai Lueang' [The Yellow Peril] on the danger of Japan, which was powerful in the economy. Numerous articles in these publications expressed a belligerent feeling toward the military dictatorship, exposed the domination of the Thai economy, Thai politics, and the Thai military by the United States of America and Japan, and also introduced successively the concepts of socialism, communism, Marxism and Maoism.

In addition to the social and political publications of the 'activist' student groups, other literary activities were 
conducted by university literary clubs. 'Literature for life' became the popular trend in writing because young writers and readers paid much more attention to the country's development and social changes. They thirsted to read books which reflected 'social conscious-ness'. Various literary activities were organized including seminars, panel discussions and book exhibitions, on the topic of contemporary literature. The literary works of the postwar era which had been banned from the bookshelves and libraries for sixteen years were reprinted. Novels, short stories, and poems of noted writers such as Sri Burapha, Seni Saowaphong, Isra Amantakul, Supha Sirimanon, Nai Phi, Banchong Banchoedsilp, and Jit Phoumisak became popular among activist university students and intellectuals. A very valuable contribution was that the concept of 'literature for life' was passed on to new generation readers and writers. The young writers wrote about the boring life in the university and the failure of the educational system. They criticized the lack of any relationship between the lectures in the classroom and the real situation outside. They discussed the difference between the nonsensical lifestyle in the university and the complex problems of the world and society. The confusion between reality and illusion made the young boys and girls question themselves about the meaning of life and the relationship between life and society. This literary period was named 'searching for the meaning of life,' which came from a line of Witayakon Chiengkul's outstanding poem 'Chan Chueng $\mathrm{Ma} \mathrm{Ha}$ Khwam Mai' [I Come to Search for the Meaning].

Besides the 'literary clubs,' there were a numerous independent groups of university writers, and they developed literary form and content. The most influential ones were Chomrom Phrachan Siao [The Crescent Moon], Num Nao Sao Suai [The Young Boys and the Beautiful Girls] and Wannakam Phuea Chiwit [Literature for Life]. These groups printed collections of short stories, poems, plays and articles written by the 'new wave' writers. Wityakon Chiengkul, Suchat Sawatsri, Nikhom Rayawa, Naowarat Phongphaibul, Sujit Wongthes, Phaibul Wongthes, Khanchai Bunpan, Sathian Chanthimathon, Surachai Chanthimathon, Kamon Kamontrakul, Anut Aphaphirom are among those renowned nowadays. In their works, these new generation writers used modern literary techniques and philosophies such as the stream of consciousness, symbolism, existentialism, surrealism, and science fiction. The content of their works was interesting too. They wrote about alienation from society, dissatisfaction with military dictatorship, the anti-war movement, human rights, injustice, social consciousness, the influence of materialism and technology, the decline of humanism, and the lack of humanity. Moreover, free verse and concrete poetry were favourites among the young poets because of the freedom from the conventional versification. We could say that these 'avant-garde' writers tried to prove that in form and content their works were free from literary conventions. In addition, they believed that the aim of literary creativity was the creation of better society.

Creative writing in this period grew in power, especially during the October 14 incident. Works by poets such as Rawi Domphrachan, Wisa Khanthap, Seksan Prasertkul, were recited among the ten thousand people during the rally. Among these poets, Rawi Domprachan was outstanding. His poems were strong and 
powerful with sharp diction. They penetrated to the hearts of the readers. Therefore, his poems became the inspiration to the student activists during the uprising of October 14. One of his popular poems was 'Tuen Thoet Serichon' [Wake Up Free Man] some lines of which became 'golden lines:'

Wake up free man!

Do not be patient to bow your head.

Any bayonet or any gun

Can not resist the wave of the stream of people.

(translated by Ruenruthai Sujjapun)

On October 13, one day before the October 14 incident, Naowarat Phongphaibul wrote 'Hon Thang Haeng Hòi Thak' [The Way of The Snail] which was beautiful and powerful. He persuaded the people to join the fighting with the great hope that:

Waiting for the day

When the blazing sun

Will lash out in anger with its rays

And consume the weeds' domain.

Then the lovely silver

Will be caught by the rays

And in the blaze like diamonds

Be consumed, the snail's track.

And the little snail will offer up its flesh

- To become a creator

From its own dissolution

As it has always been.
So there lies the way

Leading to the ideal,

As long as weeds rule

There will be hearts to struggle.

(translated by Michael Wright)

In addition to poetry, many activist short stories and novels were created at this time. They gave not only pleasure to readers but also ideas. A number of young writers began their careers in writing with works of this kind, for instance, Kon Kailas, Manop Thanomsri, Nives Kanthairat, Phibulsak Lakonpol, Makut Onruedi and Praphasson Sewikul, etc. Their short stories and novels familiarized readers with incidents and situations in society and the way of life of common people.

Some romantic novelists turned to writing realistic novels which reflected social conditions. A distinguished one is $\mathrm{Si} \mathrm{Fa,}$ whose Khwam Rak Si Phloeng [Firecolored Love] is a story about love, study and activities of the university students under the military regime, the students criticize the dictatorship. Thus, some writers at this time tried to show their responsibility to society.

The production of 'serious' fiction was actively promoted. Various literary prizes were offered by the government, the private sector, and non-profit organizations and were awarded to writers who spoke for the common people and whose works echoed public sentiment. In 1968, the Southeast Asia Treaty Organization (SEATO) inaugurated literary prizes to promote literary activities in member countries. During the four years of its 
existence, SEATO literary awards for the novel were given to Krisna Asoksin, Suwanni Sukhontha and Botan. Krisna Asoksin's Ruea Manut [Ship of Humanity] and Tawan Tok Din [Sundown] reveal human nature. Suwanni Sukhontha's Khao Chue Kan [His Name is Kan] is the story of an idealistic doctor who chooses to work upcountry. Botan's prize-winning novel was 'Chotmai Chak Mueang Thai' [Letters from Thailand] which expresses the attitudes of a Chinese man toward Thai people and culture. Likewise, later literary awards, such as the Ministry of Education Literary Award, the Lotus Literary Award, the S.E.A. Write Award, and the Cho Karaket Literary Award, have been given to recognize creative and 'serious' literary works which try to interpret life, society, and the world.

\section{Literature for Life from October 14, 1973 to October 6, 1976}

The three years between the uprising of October 14, 1973 and the violence of October 6, 1976 have been referred to as the time of 'exuberant democracy' and sometimes as the period of 'Hundred Flowers Bloom' because of the immense number of books printed. The democratic atmosphere encouraged the literary creation. Literature for life dominated the literary scene again. The October 14 incident awakened various groups of people to care for their rights and freedom and to be conscious of their role and function in society. This awareness pushed them to use their freedom in action and thought. Literature for life responded effectively to the people's search for truth and their political interests. At the same time, literature for life also seemed to be the medium of political fighting and political propaganda. During these three years, 335 political titles were published. ${ }^{15}$ This large number of books included scholarly works, fiction, non-fiction, poetry, and short stories. The literature for life corpus grew to include works written by post-war writers, those of the new generation writers, and also numerous translations of books written by socialist writers such as the sayings and poems of Mao Tze-tung, short stories by $\mathrm{Lu} \mathrm{Sin}$, political treatises by Marx and Lenin, and works by Maxim Gorgy and Chekov.

The reprinting of Jit Phoumisak's 'Art for Life and Art for People' in 1972 played an important role in setting a framework for thought about the form and content of literature for life for the young generation writers. At the same time, a seminar on the contemporary literature gave birth to the term 'wannakam nam nao' [stagnantwater literary works]. The activist critics condemned most contemporary fiction as not much different from that in the post-war period, for there was no development in plot, character, technique, or style. Their criticism extended to traditional literature, they also rejected. In an article analyzing 'wannakam nam nao,' Anut Aphaphirom declared that this kind of literary work presented personal activities, hid and distorted the truth, revealed only a veneer of truth, obstructed change, and venerated conventional beliefs. ${ }^{16}$ Later in the same year, Anut wrote another article proposing that progressive literature should:

\footnotetext{
${ }^{15}$ Bunrueang Niamhom, 1981: 123

16 Tasana Saengnam [Anut Aphaphirom]. "Wannakam Praphet Nam Nao Lae Mai Chai Nam Nao," ['Stagnant Water' Literary Works and 'Non Stagnant Water' Ones]. Khluen Luk Doem [The Same Wave]. (n.p.:Wannasilp, 1973), pp. 1-17.
} 

a) be simple and concise
b) reflect the truth of conflict among the social classes
c) be highly impressive and have strong impact
d) build a social consciousness which clearly articulates intentions and aims at definite results
e) serves the people by
i) showing the the way to change the world
ii) encouraging them
iii) destroying the enemy
vi) uplifting the masses to alertness and enlightenment
v) satisfying the masses ${ }^{17}$

At this time the separation between literature for life and literature for pleasure, or 'wannakam nam nao,' became more obvious than before. Literature for life dominated the literary stage for the young generation intellectual elite, while literature for pleasure was welcomed by housewives and factory workers. The content of literature of life at this time was the struggle of the students and common people against the government, the fighting of the laborers and the farmers against the capitalists, the hardship in the lives of the poor people, and protest and attack against conventional beliefs and values, such as religious ignorance and sexual oppression. These writers preferred writing short stories and poems to novels because the former are short, concise and could be quickly put to press. A great number of powerful poems were created during these three years. Two days after the uprising of October 14, 1973, Sujit Wongthes

\footnotetext{
${ }^{17}$ Ibid, pp. 114-115.
}

published his poem 'Wat Bot' [Wat Bot Temple] in the daily newspaper Thai Rath. Sujit adapted a version of the old lullaby 'Wat Bot' in his poem by keeping the versification and some of the content.. His poem mentions 'Khun Thòng', a hero of the Ayutthaya Period, who symbolizes the dead student heroes of the October 14 incident. This poem was very impressive, and 'Khun Thòng', the symbol of student hero, reappeared in many later literary works, such as in Atsiri Thammachot's 'Khun Thòng Khao Cha Klap Muea Fa Sang' [Khun Thòng Will Come Back in the Early Morning], which won the SEA Write Award in 1981. Naowarat Phongphaibul's 'Phiang Khwam Khluean Wai' [Mere Movement], another distinguished poem, was written in 1974. Naowarat affirms that after forty years of being silent and remaining still, the movement of the people has begun, aimed at changing society, and that ultimately the people would win, as in this excerpt:
And then a little movement,
Fair and free of filth
Unclear, still dulled
And yet a sign of life

Then the drum sounded

And the great day came.

The guns resounded

And the people fought to win.

\section{(translated by Michael Wright)}

Some other famous poems were Wisa Khanthap's 'Sip Si Tula' [October 14] and Chiranan Pitpreecha's 'Ahangka Khòng Dòkmai' [The Defiance of Flowers]. Here are excerpts from the two:

No power exists in the world, The rulers come and then go. No one is superb worshipful, 
Yet people are absolutely eternal.

When we stand firm to fight with the tyrants, People will have their new lives. When the sky turns to be golden, People will be great in the land.

('Sip Si Tula' by Wisa Khantap, translated by Ruenruthai Sujjapun)

Two hands have women, To essence they hold fast, Sinews used for work, Not in finery indulge. Two feet have women, To attain their aspiration. Together they stand, Gaining not by others' efforts.

Two eyes have women, In search of a new life, With far-reaching vision, Not amorously enticing.

('Ahangka Khòng Dòkmai' by Chiranan Pitpreecha, translated by Assoc. Prof. Malithat Phromathatavedi)

A few of the many distinguished ones of this time are Sathaphon Srisatchang's 'Kòn Pai Su Phukhao' [Before Going up to the Hill], Wat Wallayangkul's 'Khwam Nai Chai Khòng Kraduk Nai Fam Chorakhe' [In the Mind of Bones in the Crocodile Farm] and Sri Daorueang's 'Kaeo Yòt Diao' [A Drop of Glass].

In addition, some established writers began to write socially conscious fiction, such as Krisna Asoksin's 'Lom Thi Plian Thang' [The Wind Changes Its Direction], $\mathrm{Si}$ Fa's 'Tham Mai' [Why?] and Rapeepon's Phirap Daeng [Red Pigeon]. The literature for life in this period not only echoed the murder of numerous ordinary people during the uprising of October 14 but also expressed the desire to destroy the wickedness in the old society and change that society into a better one. These works awakened readers to consciousness of their rights, freedom and power. Many of them pointed to socialism and communism as the best way out for Thai society.

\section{Literature for life after the period of October 6, 1976 to the Present}

After the violence of October 6, 1976, Thailand was again a dictatorship under a civilian government. The killing of their fellows in Thammasat University on October 6 pushed many of the student activists into the forest. Many were arrested. Many were dead or missing. The rights and freedom of the mass media and the common people were limited. The creation of literature for life was suddenly stopped. The government promulgated lists of forbidden books. Many volumes of literature for life were burnt, buried, or otherwise destroyed. These books became collectors' items because the ban forbidden books had not been lifted until now.

Literature for life seemed to be 'dead,' but in fact, it was so only in the literary atmosphere of the city. On the high hills and dense forests which were the operational bases of the Communist Party of Thailand, literature for life flourished freely in newspapers and magazines printed by roneo machine and distributed to the comrades at various bases. Some of the magazines were Tawan Daeng [Red Sun], Fai $\mathrm{Pa}$ [Wildfire], Thong Patiwat [The Flag of the Revolution], Plot Aek [Liberation] and Wannakam Phuea Chiwit [Literature for Life]. These magazines published the young revolutionaries' 
poems and short stories, such as Wisa Khantap's Lò Liap Rim Phu' [Skirting Along the Hill], Yong Yasothon's Nirat Phuphan,' Chonthira Satayawattana's 'Chak Wana Su Nakhòn' [From the Forest to the City], and Wat Wallayangkul's Tai Ngao Puen' [Under the Shadow of the Gun]. ${ }^{18}$ Although these literary works did not circulate widely, their content and point of view were as strong and serious as their writers' fighting in battle.

A year later in 1977, Kriangsak Chamanan's coup d'état restored some measure of freedom. The government allowed more open expression of views in the mass media. Between 1978 and 1979 , an amnesty was granted to the students, intellectuals, and other activists who had gone into the forest after the October 6 incident, and the activist writers came back on the literary scene. Literature for life seemed to be gradually revived. A number of short stories described the events of October 6, such as 'Wan Wela Thi Phan Loei' [Time Passed By] by Sai Thai, 'Khun Thòng Chao Cha Klap Muea Fa Sang' [Khun Thòng Will Come Back at Dawn], 'Dòk Mai Thi Thoe Thue Ma' [Flowers in Her Hand], and 'Thoe Yang Mi Chiwit Yu Yang Nòi Kò Nai Chai Chan' [You are Alive, at Least in My

${ }^{18}$ A Group of Newspapermen and Writers for the People, 1999: 112-124. A Group of Writers and Newspapermen for People. 1998. 'Si Pi Khong Rueangsan Thai Nai Krabuankan Patiwat Thai 2519-2522 B.E.' [Four Years of The Short Stories in Thai Revolutional Movement during 1976-1979] Phasa Lae Nangsue, Journal of P.E.N. Thailand Centre, special issue on Thai Short Stories during 1932-1997,.29: 112-124.
Mind] by Atsiri Thammachot, 'Nori' and 'Sai La Sut' [The Latest "Leftist"] by Wanit Charungkitanan.

At the same time, literature for life was questioned and re-defined by critics and writers. 'Literature for life' writers began to review the doctrinaire prescriptions of the 'Literature for Life' movement. They found that many works were written according to formulae such as the 'evil capitalists' versus 'virtuous peasants' and most of them propagandized so much that they lacked reality and poetic value. The painful experiences in the forest, the maturation of writers and readers and also the changing social atmosphere released literature for life from Marxist-socialist theory. This also caused the term 'literature for life' to fall into desuetude, to be replaced by terms like 'wannakam sang san' [creative literary works], 'wannakam sathòn sangkhom' [literary works reflecting society] and 'wannakam sadaeng chit samnuek thang sangkhom' [socially conciousness literary works]. Some critics said that literature for life was already dead, and however discouraging this might have been, it was a challenge to thought.

Though similar in name, 'literature for life' differed from 'songs for life.' The latter appealed to specific audiences and had specific characteristics which distinguished them from the pop songs and country songs. However, the literature for life written in the previous two decades displayed such great variety in form and content that there were no definite criteria except social concern.

This lack of definite criteria, however, may be taken as a sign of the ongoing development of literature for life. The contemporary writers are no longer 
dominated solely by politics; they are also seriously conscious of the variety and complexity of social problems. The social problem now is not only injustice, nor is the enemy of the citizens only the government. The new enemies of people are intangibles like the economy and technology which troubles both rich and poor alike. Problems of real-estate concern both farmers and landdevelopers. Problems of industrial production concern both capitalists and laborers. The social, economic, technological problems all affect the family. Divorce is caused not by a third person but by economic problems. Parents do not have enough time to bring up their children because of their financial problems. Also, the victory of capitalism and liberalization of the economy increase pressures within the society and the resultant competition adds much more to selfishness than to sympathy. Thus, writers are interested in humanism and individualism as well as the 'inside' of human beings. Moreover, the problems of the middle class in the big city are as interesting to the writers as those of rural folk upcountry. In short, creative writers are trying to explain failures in education, the economy, politics, religion, culture, and all other components of the social system which affect every person.

Most of the literary works of the past two decades show more concern with the interrelationship between man and man, man and society, and man and-technology. For their content, they take the decline of rural life, alienation in the big city, religious beliefs, failures of the educational system, environmental awareness, outdated social and cultural values, the decline in morals and ethics, Western influences, and the power of science and technology. 'Kham Phiphaksa' [The Judgement] written by
Chat Kobchitti is a good example. Chat tells us about the conflict between the 'individual' and 'society'. He also asks what is fact, why what's right in one's sight can be wrong in another's and vice versa. This novel won the S.E.A Write Award in 1982. In 1996, the same writer again won the S.E.A Write Award for Wela [Time], which is about old people in a home for the elderly. 'Mit Pracam Tua' [Personal Knife], a short story written by Chat, depicts 'man-eat-man' society with the techniques of symbolism and surrealism. Nikhom Rayawa's 'Takuat Kap Khop Phu' [The Monitor Lizard and the Rotten Bough] illustrates the fact of life that the world consists equally of both goodness and badness. In his 'Taling Sung Sung Nak' [High River Bank and Heavy Log], which won the S.E.A Write Award in 1988, Nikhom gives the readers an understanding of the real value of life through an elephant man's life. The collection of short stories Luk Phò Khon Nueng Thak Mai Muean Ma Lia [A Father's Son Hews Wood Like Dog Licks] by Wat Wallayangkul describes humanity, the reason and the result of existence, the relationship between life and the surroundings. He shows the relatedness of all things and the importance of man's capabilities as well as his deficiencies and inferiority by nature. 'Fai Phrang Thian' [Lights Dim Candles], a collection of short stories by Mala Khamchan, is concerned with the modernization of the country which destroys the old traditions and culture. While 'Himaphan' by Sanan Chusakul warns of the dangers of insecticide to farmers who plant cashew nut trees, 'Khondo Sut Sai Rung' [Condominiums at the End of the Rainbow] by Parinya Trinoysai points to the danger of toxic emissions from an electric power plant present to rich people living in sky-high condominiums. 
Chamlong Fangcholchit has pictured city people who are isolated, busy, lonely and confused. In his latest collection 'Mueang $\mathrm{Na} Y \mathrm{Y}^{\prime}$ ' [A Livable City], Chamlong retains this theme but is more optimistic. $\mathrm{He}$ seems to tell us that acceptance of unhappiness as a part of life is the only way to attain happiness. $\mathrm{He}$ also encourages us with the thought that every problem can be solved; otherwise, we should not think of it as a problem. The influence of violence on television and in video games on children is dealt with in 'Dòk Lueat' [Bloody Flowers], a short story by Sila Khomchai and 'Yuea' [The Victim], a novel by Botan. The power of the mass media who, without humanity, 'sell' disasters that befall their fellowmen for their own benefit is exposed in 'Nai Thi Satharana Lae Thuk Tòng Tam Kotmai' [In a Public and Legal Place] by Phaithun Thanya and 'Kradat Khao Lae Khao Muek' [White Paper and Stinking Ink] by Win Liaowarin.

The violent incidents of October 14, 1973 and October 6, 1976 and also Black May of 1992 remain ever in the minds of those who are over 30 years old and continue to inspire contemporary writers. Many works of fiction and of non-fiction, in poetry and in prose describe the violence and pain of these events. Nevertheless, we could say that the writers' maturity and experience as well as the social changes encourage them to look back to the past with understanding and look to the future with hope and courage. We can see this tendency in many works such as the poems 'Ramruek Thop Thuan Ròi Thao Haeng Withi [Looking Back on the Path of Footprints] by Saksiri Misomsuep, 'Khrai Khit Luem Khrap Nam Ta Prachachon Cha Thuk Khon Phiphaksa Prachathan' [One Who Forgets the People's Stain of Tears Will be Lynched] by Duenram
Prakairueang, and 'Lilit La Khamsuan' by Kanti $\mathrm{Na}$ Sattha, in the novels Prachathipatai Bon Sen Khanan [Democracy on Parallel Lines] by Win Liaowarin and Chak Duang Ta Dòk Mai [From the Flowers' Eyes] by Chamaiphon Saengkrachang, and in the short stories 'Phaen Din Khòng Khao' [His Land] and 'Phi Yu Nai Ban' [Ghosts in the House] by Kanokphong Songsomphan.

We can conclude that 'literature for life' is a genre of Thai contemporary literature which is influenced by the concept of 'art for art's sake'. This literary movement was introduced into literary circles beginning in 1947 though the articles of Nai Phi and Banchong Banchoedsilp and later though the article 'Art for Life and Art for People' by Jit Phoumisak. The progressive writers between 1947 and 1957 accepted this concept and seriously applied it in their literary works. Thus, literature for life became the mainstream of literary creation at that time, but it was repressed during the literary darkness of Sarit's dictatorial regime (1958-1964). After this, however, the 'Art for Art and Art for People' movement gradually recovered, and in the period of 'Searching for Truth' by the university student activists after the uprising of October 14, 1973, literature for life bloomed and dominated the literary scene. Numerous 'literature for life' publications written by the post-war authors were reprinted as were works created by their new generation successors. The stream of 'literature for life' flowed strong for a mere three years. The violent October 6, 1976 incident put the literature for life to death because many copies of these works were destroyed and almost all the writers of this genre escaped into the forests. After the granting of amnesty in 1979, political struggle decreased and society became 
more democratic. With discussion of and comment on form and content, the stream of 'literature for life' began to flow. Progressive literary works were no longer influenced by the Marxism and socialism, and so the term 'literature for life' came to be applied particularly to literary works produced during the time surrounding the two October incidents. Some critics nowadays hold that the era of literature for life has ended. In fact, though, the 'literature for life' writers before and after October 14, 1973 have continued to create literary works. While the term 'literature for life' is not widely used by contemporary writers, we cannot deny that the concepts of political thought and social consciousness are transferred endlessly to the 'new-wave' writers. They develop their attitudes and their points of view. They understand human beings, they understand society and they care for what happens to the world. They reflect the reality of life and society with their wide vision, profound experiences and tranquillity. Literature for life will remains as long as writers show responsibility to their society. Thus, the essence of 'art for life' is still a powerful influence in contemporary literature, whether it is called 'literature for life' or not.

\section{References}

A Group of Writers and Newspapermen for People. 1998. 'Si Pi Khòng Rueagsan Thai Nai Khabuankan Patiwat Thai 2519-2522 B.E.' [Four Years of The Short Stories in Thai Revolutionary Movement during 1976-1979] Phasa Lae Nangsue, Journal of P.E.N. Thailand Centre, Special Issue on Thai Short Stories during 1932-1997. 29:112-124.
Banchong Banchoedsilp. 1981. Silpa Wannakhadee Kap Chiwit [Literary Art and Life]. n.p.: Saithip.

Chaisiri Samutawanit. 1981. Wannakam Kan Mueang Thai Sip Si Tula Nueng HokHok Tula Nueng Kao [Thai Political Literature October 14, 1973-October 6, 1976]. n.p.: Sangsan.

Naowarat Phongphaibun. Mere Movement, Special Edition, Thai and English. n.p.: Ko Kai.

Nitaya Masavisut and Matthew Grose, eds. 1996. The S.E.A. Write Anthology of Thai Short Stories and Poems. Chiangmai: Silkworm Books.

Phailin Rungrat [Chamaiphon Saengkrachang]. 1998. 'Sam Pi Dòk Mai Ban Ròi Dòk Wannakam Phuea Chiwit Ban Ròi Reuang 2516-2519 B.E..' [Three Years of 1973-1976: Hundred Flowers Bloomed, Hundred Literature for Life were Created] Phasa Lae Nangsue, Journal of P.E.N. Thailand Centre, Special Issue on Thai Short Stories during 19321997,.29: 103-124.

Phinyo Kongthong. 1965. The Progressive Characteristics in Short Stories during 1967-1973. M.A. Thesis. Sri Nakharinwirot University.

Ruenruthai Sujjapun. 1998. 'Yi Sip Ha Pi Sip Si Tula: Mòng Phan Wannakam Pheua Chiwit' [25 Years of October 14, 1973: Look though the Literature for Life]. Yi Sip Ha Pi Sip Si Tula: Mòng Phan Wannakam Phuea Chiwit/ Phap Doy Ruam Khong Kawiniphon Phuea Chiwit (October 14,1973-October 6, 1976).

Sathian Chanthimathon.1982. Sai Than Wannakam Phuea Chiwit Khòng Thai [The Stream of Thai Literature for Life]. n.p.: Chao Phraya. 
Suchat Sawatsri. 1998. 'Chitsamnuek Kabot Nai Rueangsan Thai 2506-2519 B.E.' [The 'Rebellious Spirit' in Thai Short Stories from 1963 to 1976'] Phasa Lae Nangsue, Journal of P.E.N. Thailand Centre, Special Issue on Thai Short Stories during 19321997,.29 (1998): 70-102.

Tasana Saengnam [Anut Aphaphirom]. 1973. "Wannakam Praphet Nam Nao Lae Mai Chai Nam Nao. "['Stagnant Water' Literary Works and 'Non Stagnant Water' Ones]. Khluen Luk Doem [The Same Wave]. n.p.: Wannasilp, 1973

Thipakon [Jit Phoumisak]. 1972. Sinlapa Phuea Chiwit, Sinlapa Phuea Prachachon [Art for Life, Art for People]. n.p.: Nangsue, 1972.
The Committee of the ' 25 Years of October 14' Project. 1998. 'Rueang San Thai 2575-2510 B.E.' [Thai Short Stories during 1932-1967, Phasa Lae Nangsue, Journal of P.E.N. Thailand Centre,.Special Issue on Thai Short Stories during 1932-1997,.29 (1998): 25-69.

Trisilp Bunkachon.1980. The Novel and Thai Society 1932-1957. n.p.: Sangsan.

Yurachat Bunsanit. 1999. 'Rueangsan Si Rai 2524-2539 B.C.' [S.E,A. Award Short Stories 1981-1996], Phasa Lae Nangsue, Journal of P.E.N. Thailand Centre, Special Issue on Thai Short Stories from 1932 to1997,. 29 (1998): 159-208. 